\title{
OPPORTUNISTIC BACTERIA IN AGROECOSYSTEMS OF UKRAINE
}

\author{
L. M. Butsenko, L. A. Pasicnhyk \\ DANYLO ZABOLOTNY INSTITUTE OF MICROBIOLOGY AND VIROLOGY OF THE NATIONAL ACADEMY \\ OF SCIENCES OF UKRAINE, KYIV, UKRAINE
}

Background. Recently, the number of diseases caused by opportunistic bacteria has been increasing all over the world. Opportunistic microorganisms are characterized by ubiquitous proliferation, flexibility in adaptation to the conditions of the environment, lack of specific relationship with the macroorganism. Phytopathogenic bacteria are also able to infect both plants and animals.

Objective. The purpose of the research was to detect the Pantoea agglomerans and Pseudomonas fluorescens bacteria in various ecological niches and establish their virulence.

Methods. Classical microbiological, biochemical, serological methods were used in the research. The identification of bacteria was carried out according to their phenotypic properties.

Results. It has been established that opportunistic bacteria species P. agglomerans and P. fluorescens are present in wheat agrophytocenoses. The bacteria isolated from the agrophytocenoses are virulent for wheat, rye and weed plants. Antibodies to opportunistic bacteria, which are spread in agrophytocenoses of cereals crops, have been found in the blood of healthy rabbits.

Conclusions. Thus, we have established that virulent strains of opportunistic bacteria P. agglomerans and $P$. fluorescens are spread in agrophytocenoses of cereals. The presence of antibodies to these bacteria in the blood of healthy rabbits proves that opportunistic bacteria from plant material get into animals and humans. Knowledge of biology and the spread of opportunistic pathogens in agrophytocenoses is necessary for prevention of infections that these bacteria cause in humans.

KEY WORDS: opportunistic bacteria; Pantoea agglomerans; human health.

\section{Introduction}

Recently, the number of diseases caused by opportunistic bacteria has been increasing all over the world. Opportunistic microorganisms are characterized by ubiquitous proliferation, flexibility in adaptation to the conditions of the environment, lack of specific relationship with the macroorganism. Such bacteria are characterized by the ability to cause nonspecific toxic infections in weakened people and animals.

It has been established that strains of certain species of microorganisms can cause damage to plants, insects, animals and humans [1]. This phenomenon is known as polybiotrophy [2], which is particularly spread among opportunistic microorganisms. For example, conditionally pathogenic bacteria for humans Pseudomonas aeruginosa cause an internal of putrefaction onion during storage [3]. Strains $P$. aeruginosa, isolated from sick people, under

Corresponding author: Liudmyla Butsenko, Department of Phytopathogenic Bacteria, Zabolotny Institute of Microbiology and Virology of the National Academy of Sciences of Ukraine, 154, Akademika Zabolotnoho Str., Kyiv, 03680, Ukraine E-mail: plant_pathol@ukr.net experimental conditions affect plants, nematodes and insects [4]. Phytopathogenic bacteria are also able to infect both plants and animals $[1,2]$. Bacteria of the genus Erwinia, which are well known exclusively as pathogenic to plants, are often isolated in pathological processes in humans and animals [5]. In this case isolates isolated from humans and animals are pathogenic to plants [2]. The causative agent of vascular bacteriosis of Erwinia toxica cucumbers, in intraperitoneal administration to mice, leads to sepsis in animals. Infected with these bacteria fruits of cucumbers cause poisoning in people [6].

A high degree of similarity established by DNA hybridization analyses and phenotypic data between strains of Erwinia herbicola, Enterobacter agglomerans and Erwinia milletiae led Gavini et al. [7] to unite them as a single species, namely Pantoea agglomerans (Beijerinck 1888) comb. nov. P. agglomerans is widespread in numerous diverse natural habitats and is particularly associated with many different plants as a common epiphyte and endophyte [8]. Additionally, it has been also isolated from seeds, water, humans (e.g., wounds, blood, 
urine and internal organs) as well as from animals [7, 9-12].

Pantoea species are ubiquitous in nature and occasionally are associated with infections caused by contaminated clinical material. Hence, Pantoea agglomerans is considered as an opportunistic pathogen of humans [13].

The Pseudomonas fluorescens bacteria, under conditions favorable to their development, can cause diseases of agricultural crops [14]. For some human diseases, antibodies to $P$. fluorescens lipopolysaccharide have been identified in the patients' blood.

Therefore, the purpose of the research was to detect the Pantoea agglomerans and Pseudomonas fluorescens bacteria in various ecological niches and establish their virulence.

\section{Methods}

Materials for research were the plants with symptoms of damage of rye, wheat and weeds that grew in wheat agrocenoses. Bacteriological analysis and isolation of bacteria were carried out using generally accepted methods [15]. Virulent properties were investigated on the host: plant, aggressiveness of the pathogen was determined by a 4-point scale. The biological properties were investigated by the methods described by Klement et al [15]. The bacteria were identified by comparing their properties with the characteristics of strains collection, and according to the Bergey's Manual of Systematic Bacteriology [16].

\section{Results}

We have found out that yellow-pigmented bacteria, flat or with a conical center, are opaque, wavy edges; and the oxidase-positive gray-colored isolates with wavy edges were isolated from all investigated plant materials.

It was established that a part of the investigated isolates of bacteria was avirulent for plants. In all other cases, the isolated bacteria caused diseases of rye, wheat and weeds.

The yellow pigmented bacteria are polymorphic, short rods, single arranged, sometimes in pairs in the form of short chains. Bacteria are mobile, Gram negative, spores are not formed, oxidase negative. Facultative anaerobes (Table 1). On the meat-peptone broth they grow with the formation of uniform turbidity, ring, film and sediment. The bacteria are utilized glucose (anaerobic), reduce nitrates, acidify litmus serum. Strains differ in the use of rafinose, sorbitol and inulin. All investigated strains do not use dulcitol, cause coagulation or peptonization of milk.

The isolates obtained from the affected plants according to the physiological and

Table 1. Physiological and biochemical properties of isolates

\begin{tabular}{|c|c|c|c|c|}
\hline Test & $\begin{array}{l}\text { Yellow-pigmented } \\
\text { isolates }\end{array}$ & $\begin{array}{c}\text { P.agglomerans } \\
{[16]}\end{array}$ & $\begin{array}{c}\text { Unpigmented } \\
\text { isolates }\end{array}$ & $\begin{array}{c}\text { P.fluorescens } \\
{[16]}\end{array}$ \\
\hline Gram's staining & - & - & - & - \\
\hline Motility & + & + & + & + \\
\hline Nitrate reduction & + & + & - & - \\
\hline Oxidase & - & $\mathrm{n} / \mathrm{i}$ & + & + \\
\hline Formation of $\mathrm{H}_{2} \mathrm{~S}$ & $-1+$ & $\mathrm{n} / \mathrm{i}$ & - & $n / i$ \\
\hline Formation of indole & - & - & - & $n / i$ \\
\hline Gelatinase & $+/-$ & + & + & $n / i$ \\
\hline OF-test & $\begin{array}{c}\text { Facultative } \\
\text { anaerob }\end{array}$ & $\begin{array}{c}\text { Facultative } \\
\text { anaerob }\end{array}$ & Aerob & Aerob \\
\hline $\begin{array}{l}\text { Utilization: } \\
\text { D-glucose, L-arabinose, } \\
\text { D-mannitol, D- xylose }\end{array}$ & + & + & + & + \\
\hline Fructose, galactose & + & + & + & $\mathrm{n} / \mathrm{i}$ \\
\hline Salicin & + & + & - & - \\
\hline Lactose & + & $d$ & - & - \\
\hline Inositol & + & + & $+1-$ & + \\
\hline Raphinose & $+1-$ & $d$ & $+1-$ & $n / i$ \\
\hline Dulcitol & - & - & $+1-$ & $n / i$ \\
\hline Sorbitol & $+/-$ & - & $+1-$ & + \\
\hline Inulin & $+1-$ & $\mathrm{n} / \mathrm{i}$ & & \\
\hline
\end{tabular}

Note: $n / i-$ not investigated. 
biochemical properties are similar to each other and do not differ from the characteristics of the described $P$. agglomerans species [16]. According to this they were identified as $P$. agglomerans.

Gray colored oxidase-negative bacteria grow on the meat-peptone broth, form a film, ring and precipitate, and use glucose (aerobic), mannitol, xylose, fructose, arabinose, and do not utilize lactose, inulin, salicin, as a single source of carbon.

Most of the isolates utilize raffinose, maltose and dulcitol. All isolates hydrolyze gelatin, alkalinize the litmus serum, and do not reduce nitrates (Table 1). The isolates of bacteria obtained from the affected cereals and weeds on the morphological and cultural-biochemical properties did not differ from the described strains of $P$. fluorescens and from the $P$. fluorescens characteristic given in Bergey's Manual of Systematic Bacteriology [16].

All bacterial strains tested were virulent for wheat, rye and weed plants (Table 2). It was established that the strains of the isolated bacteria are more aggressive on weeds than on agricultural crops.

Consequently, pathogenic bacteria for plants of the species Pantoea agglomerans and Pseudomonas fluorescens are able to come into contact with humans and animals and cause their diseases. This is evidenced by the fact that we detected antigens to the strains Pantoea agglomerans and Pseudomonas syringae pv. syringae in the serum of non-immunized rabbits (true phytopathogen) (Table 3).

Thus, the study of phytopathogenic and opportunistic bacteria is important not only for the development of plant protection methods, but also from the point of view of studying their effects on human health, since these bacteria are widespread in nature and can be ingested by humans.

\section{Discussion}

Our research has found that rye, wheat and weeds that grow in the agroecosystem of wheat are affected by opportunistic bacteria Pantoea agglomerans and Pseudomonas fluorescens. Our previous studies proved that strains of $P$. agglomerans and $P$. fluorescens were more commonly found in agricultural crops as epiphytes and did not cause plant diseases [17]. With the change of environmental factors and the influence of agronomic techniques, these opportunistic bacteria in recent years increasingly acquire virulent properties. For example, the bacteria of $P$. agglomerans were isolated from the affected locales of cotton bolls collec ted in a field in the USA and were able to cause comparable disease symptoms in greenhouse grown cotton fruit [18].

P. agglomerans, gram negative bacteria of Enterobacteriaceae family, were isolated from feculent material, plants and soil. Soft tissue and bone-joint infections due to $P$. agglomerans following penetrating trauma by vegetation and bacteraemia in association with intravenous fluid, total parenteral nutrition, blood products and anesthetic agent contamination were reported [19]. Some authors on the basis of their studies suggested that, independent of their origin, all $P$. agglomerans strains might possess indistinguishable virulence potential [13]. P. agglomerans was also proved to be an antibiotics producer [20].

Some researchers reported on isolation of P. agglomerans in two cases of septic monoarthritis after plant thorn and wood sliver injuries [21]. This indicated the transfer of $P$. agglomerans from the infected plant material to humans.

Table 2. Virulence properties

\begin{tabular}{|l|c|c|c|}
\hline \multirow{2}{*}{ Species } & \multicolumn{3}{|c|}{ Aggressiveness (marks) on plant: } \\
\cline { 2 - 4 } & Rye & Wheat & Weed \\
\hline Pantoea agglomerans & $1-2$ & $1-3$ & $2-3$ \\
\hline Pseudomonas fluorescens & $1-2$ & 2 & $2-3$ \\
\hline
\end{tabular}

Table 3. Results of agglutination reaction

\begin{tabular}{|l|c|c|}
\hline \multirow{2}{*}{ Species, strains } & \multicolumn{2}{|c|}{$\begin{array}{c}\text { Titres of agglutination reaction with sera } \\
\text { of non-immunized rabbits }\end{array}$} \\
\cline { 2 - 3 } & Serum 1 & Serum 2 \\
\hline Pantoea agglomerans, 116 & 50 & 200 \\
\hline $\begin{array}{l}\text { Pseudomonas syringae pv. syringae, } \\
\text { NCPPB 281 }\end{array}$ & 200 & 0 \\
\hline Erwinia amylovora, 2024 & 0 & \\
\hline
\end{tabular}


When studying the effect of bacteria of the genus Klebsiella (K. pneumoniae, K. hinoscleromatis, K. ozaenae), which, like the Erwinia phytopathogenic genus, belonged to the Enterobacteriaceae family, on leaves of potatoes, horse beans, beans, cabbage, cucumber, pumpkin and apple fruits Jonathan found out that four strains of $K$. pneumoniae were capable to affect horse beans and potatoes. The phytopathogenic properties of Klebsiella species did not correlate with their ability to produce pectinases [22].

At the same time, phytopathogenic properties can be presented by bacteria, which are traditionally pathogens of animals and humans. It is proved that $15 \%$ of the strains of bacteria of genera Escherichia, Citrobacter, Enterobacter, Proteus, Pseudomonas, isolated from urological patients, have phytopathogenic properties. The most pronounced these properties were on fruits of tomatoes [23].

Among the species of the genus Pseudomonas, which produce pigments ( $P$. aeruginosa, $P$. fluorescens, P. aureofaciens), it is proved that the strains have phytotoxic and entomocidal properties. The greatest number of such strains is found among the bacteria of P.fluorescens species. The cultural fluid of these strains suppresses the germination of seeds of radish, lettuce and, to a lesser extent, wheat, and also causes the death of $100 \%$ of mosquito larvae. Entomopathogenic strains of $P$. fluorescens have antagonistic effects on some saprophytic bacteria (Bacillus subtilis, B. megaterium, Sarcina lutea, Escherichia coli, Mycobacterium sp.). Thus, the toxins of pigmented strains of the genus Pseudomonas are not narrowly specific and affect a wide range of organisms [24]. In some human diseases antibodies to the lipopolysaccharide of $P$. fluorescens 7769 , which were isolated from affected rye tissues, were identified [25].

The adaptation of $P$. agglomerans to diverse microenvironments might suggest that this species maintain high genetic plasticity. $P$. agglomerans appears to be readily accessible to horizontal gene transfer driven by plasmids and other mobile elements [26], a trait that may explain its flexibility in adapting to different life styles.

Some researchers noted that pathogenic microorganisms had a lot in common in mechanisms of pathogenicity, regardless of which macroorganism they were infected with [1, $27,28]$.

\section{Conclusions}

Thus, in the agrophytocenosis of wheat, one of the most widespread agricultural crops in Ukraine, there are virulent strains of opportunistic bacteria of $P$. agglomerans and $P$. fluorescens species. Present agroecosystems, which are overloaded with chemical pollutants, create conditions for increasing the aggressiveness of opportunistic bacteria. It has been established that in the blood of healthy rabbits antibodies to opportunistic bacteria, which are spread in agrophytocenoses, are present. It proves the intake by animals of opportunistic bacteria together with plant food. Since opportunistic bacteria can cause the infections processes in humans, animals, insects and plants, the control of their spread and investigation of peculiarities of virulent strains circulation is necessary.

\section{ОПОРТУНІСТИЧНІ БАКТЕРІЇ В АГРОЕКОСИСТЕМАХ УКРАЇНИ}

Л. М.Буценко, Л. А. Пасічник ІНСТИТУТ МІКРОБІОЛОГЇ̈ І ВІРУСОЛОГЇ̈ ІМЕНІ Д. К. ЗАБОЛОТНОГО НАН УКРӒ̈НИ, КИЇВ, УКРАЇНА

Вступ. Останнім часом кількість захворювань, спричинених опортуністичними бактеріями, зростає в усьому світі. Опортуністичні мікроорганізми характеризуються значними темпами проліферації, гнучкістю в адаптації до умов навколишнього середовища, відсутністю специфічних зв'язків з макроорганізмом. Фітопатогенні бактерії також здатні інфікувати як рослини, так і тварини.

Метою дослідження було виявлення бактерій Pantoea agglomerans i Pseudomonas fluorescens в різних екологічних нішах і встановлення їх вірулентності.

Методи дослідження. У дослідженні використовувалися класичні мікробіологічні, біохімічні та серологічні методи. Ідентифікацію бактерій було здійснено за їх фенотиповими властивостями.

Результати дослідження. Встановлено, що в агрофітоценозах пшениці присутні опортуністичні бактерії виду P. agglomerans і P. fluorescens. Виділені бактерії вірулентні для рослин пшениці, жита та бур'янів. Антитіла до опортуністичних бактерій, які поширюються в агрофітоценозах зернових культур, виявлені в крові здорових кроликів.

Висновки. Встановлено, що вірулентні штами опортуністичних бактерій $P$. agglomerans ma $P$. fluorescens поширюються в агрофітоценозах зернових культур. Наявність антитіл до цих бактерій у крові здорових кроликів доводить, що опортуністичні бактерії з рослинного матеріалу потрапляють в організми тварин і людини. Знання біології та поширення опортуністичних патогенів в агрофітоценозах необхідні для профілактики інфекцій, що викликаються цими бактеріями в організмі людини.

КЛЮЧОВІ СЛОВА: опортуністичні бактерії; Pantoea agglomerans; здоров'я людини. 


\section{References}

1. Cao H, Baldini RL, Rahme LG. Common mechanisms for pathogens of plants and animals. Ann Rev Phytopathol. 2001;39:259-284.

2. Gvozdyak RI. Polybiotrophy of bacteria. Microbiol Z.1981;43(2):256-262.

3. Gvozdyak RI, Yakovleva LM. On the peculiar features of the pathogenicity of Pseudomonas aeruginosa. J Microbiol Epidemiol Immunol. 1987;3: 3-6.

4. Mahajan-Miklos S, Rahme LG, Ausubel FM. Elucidating the molecular mechanisms of bacterial virulence using non-mammalian hosts. Mol Microbiol. 2000;37(5):981-988.

5. Starr MP, Chatteriee AK. The genus Erwinia: enterobacteria pathogenic to plant and animals. Ann Rev Microbiol. 1972;26:389-426.

6. Gvozdyak RI. Korobko AP, Lemeshchenko GP Zoopathogenic properties of the causative agent of vascular bacteriosis of E. toxica cucumbers. In Phytopathogenic bacteria. Kyiv: Nauk. dumka, 1975: 88-91.

7.Gavini F, Mergaert J, Beji A, Mielcarek C, Izard D, Kerster K, De Ley J. Transfer of Enterobacter agglomerans (Beijerinck 1988) Ewing and File 1972 to Pantoea gen. nov. as Pantoea agglomerans comb. nov. and description of Pantoea dispersa sp. nov. Int J Syst Bacteriol.1989;39:337-345.

8. Kobayashi DY, Palumbo JD. Bacterial endophytes and their effects on plants and uses in agriculture. In Microbial Endophytes. Bacon CW, et al. (eds). Basel, Switzerland: Marcel Dekker Inc. 2000;199-233.

9. Cruz AT, Cazacu AC, Allen CH. Pantoea agglomerans, a plant pathogen causing human disease. J Clinical Microbiol. 2007;45:1989-1992.

10. Williams AJ, Scott RJ, Lightfoot NF. Erwinia herbicola as a cause of bacterial endocarditis. J Infect. 1986;12(1):71-3.

11. Milanowski J, Dutkiewicz J, Fafrowicz B. Pathogenic action of Erwinia herbicola. II. In vivo investigations. Pneumonol Alergol Pol. 1993;61(1112):598-605.

12. Silva MC, Attademo FF, Freire AC, Sousa GP, Luna FO, Lima DC et al. Identification of bacteria in blood cultures from clinically ill captive antillean manatees (trichechus manatus manatus). J Zoo Wildl Med. 2017;48(1):13-17. doi: 10.1638/2015-0094.1.

13. Völksch B, Thon S, Jacobsen ID, Gube M. Polyphasic study of plant- and clinic-associated Pantoea agglomerans strains reveals indistinguishable virulence potential. Infect Genet Evol. 2009;9(6):138191. doi: 10.1016/j.meegid.2009.09.016.

14. Gvozdyak RI, Pasichnyk LA, Yakovleva LM, Moroz SM, Lytvynchuk OO, Zhytkevych NV, et al. Fitopatohenni bakterii. Bakterialni khvoroby roslyn. Kyiv: TOV 'NVP Interservis'; 2011.V.1:444 p.
15. Klement Z, Rudollf K, Sands D. Methods in phytobacteriology. Budapest, Academia Kiado; 1990: $568 \mathrm{p}$.

16. Bergey's manual of systematic bacteriology. Boore DR, Castenholz RW editors, Vol. 1: Garrity GM, editor-in-chief. 2nd ed. New York, Berlin, Heidelberg: Springer, 2005; 2, Part B: 1106 p.

17. Pasichnyk LA, Gvozdyak RI, Khodos SF. Epiphytic and endophytic microflora of healthy seeds and wheat plants. Bulletin of the SU, series Biology. 2005; 2(15):141-148.

18. Medrano EG, Bell AA. Role of Pantoea agglomerans in opportunistic bacterial seed and boll rot of cotton (Gossypium hirsutum) grown in the field. J Appl Microbiol. 2007; 102:134-143. DOI: 10.1111/j.1365-2672.2006.03055.x

19. Izzo I, Lania D, Castro A, Lanzini F, Bella D, Pagani A, Colombini P. Seven cases of port-a-cath contamination caused by Pantoea agglomerans in the Oncological Service of Iseo Hospital, Brescia (Italy). Infez Med. 2014;22(2):152-5.

20. Wright SA, Zumoff $\mathrm{CH}$, Schneider L, Beer SV. Pantoea agglomerans strain EH318 produces two antibiotics that inhibit Erwinia amylovora in vitro. Appl Environ Microbiol. 2001;67:284-292.

21. De Champs C, Le Seaux S, Dubost J, Boisgard S, Sauvezie B, Sirot J. Isolation of Pantoea agglomerans in two cases of septic monoarthritis after plant thorn and wood sliver injuries. J Clin Microbiol. 2000; 38(1):460-1.

22. Turyanitsa AI, Korobko AP. Phytopathogenic properties of bacteria of the genus Klebsiella. Microbiol Z. 1983;45(6):88-89.

23. Gvozdyak RI, Khodos SF, Chaikovskaya VL. Phytopathogenic properties of bacteria isolated from urological patient. Microbiol Z. 1986;48(2):30-33.

24. Mikhnovskaya ND, Shevtsova NI, Ruban EM, Lysenko LN, Vasilevskaya IA. Problem on nonspecific toxigenicity of certain representatives of the genus Pseudomonas. Microbiol Z. 1988;50(5):83-86.

25. Zdorovenko GM, Gvozdyak RI, Gubanova NYa, Afonina GB, Zdorovenko EI. Characterization of the lipopolysaccharide from $\mathrm{f}$ Pseudomonas fluorescens (Biovar I). Mikrobiology. 1999;68(3):330-339.

26. Barash I, Manulis-Sasson S. Virulence mechanisms and host specificity of gall-forming Pantoea agglomerans. Trends in Microbiol. 2007;15: 538-545.

27. Kempf VAJ, Hitziger N, Riess T, Autenrieth IB. Do plant and human pathogens have a common pathogenicity strategy? Trends in Microbiol. 2002; 10(6):269-275.

28. Rahme LG, Stevens EJ, Wolfort SF, Shao J, Tompkins RG, Ausubel FM. Common virulence factors for bacterial pathogenicity in plants and animals. Science. 1995;268(5219):1899-1902.

Received: 2018-04-27 